\title{
KETRAMPILAN MEMBACA PADA PEMBELAJARAN BAHASA INDONESIA DI SD/MI
}

\author{
Suparlan \\ STIT Palapa Nusantara Lombok NTB \\ maniahparlan66@gmail.com
}

\begin{abstract}
Language is a system, meaning that the language is formed by a component that is permanently patterned and can be explored. As a system, language is not only systematic but also systemic. By systemic, it means that the language is arranged according to a certain pattern, not arranged randomly or carelessly. Whereas systemic means, the language system is not a single system but consists of subsystems. The ability to read skills is a very important skill in life, not only important in educational life, but also very important in social life. By reading students will know more about everything, students will also have broader knowledge and insights. Reading skills are the main capital of students. With this ability, students can learn other sciences, can communicate their ideas and be able to express themselves.
\end{abstract}

Keywords: Reading Skills, Language Learning

\begin{abstract}
Abstrak: Bahasa merupakan sebuah sistem, maksudnya bahwa bahasa tersebut dibentuk oleh sebuah komponen yang berpola secara tetap dan dapat dikaedahkan. Selain itu bahasa juga bersifat sistemis. Dengan sistemis maksudnya bahasa tersebut tersusun berdasarkan suatu pola tertentu, bukan secara acak apalagi sembarangan. Adapun sistemis maksudnya, sistem bahasa bukan merupakan sebuah sistem tunggal melainkan terdiri dari subsistem. Kemampuan keterampilan membaca merupakan keterampilan yang sangat penting dalam kehidupan, tidak hanya penting dalam kehidupan pendidikan, tetapi juga sangat penting dalam kehidupan bermasyarakat. Dengan membaca peserta didik akan lebih mengetahui segala sesuatu, peserta didik juga akan memiliki pengetahuan dan wawasan yang lebih luas lagi. Keterampilan membaca merupakan modal utama peserta didik. Dengan kemampuan tersebut, peserta didik dapat mempelajari ilmu lain, dapat mengomunikasikan gagasannya dan dapat mengekspresikan dirinya.
\end{abstract}

Kata Kunci: Keterampilan Membaca, Pembelajaran Bahasa

\section{PENDAHULUAN}

Anak Sekolah Dasar adalah semua anak yang berada pada rentang usia 7-12 tahun, yang berada dalam proses perkembangan. Dimana dalam proses perkembangan tersebut seorang anak mengalami perubahan dan mulai belajar menguasai tingkatan-tingkatan yang lebih tinggi dari aspek-aspek gerakan, berpikir, perasaan, dan interaksi baik dengan teman sebaya maupun dengan Fondatia : Jurnal Pendidikan Dasar

Volume 5, Nomor 1, Maret 2021; 1-12 https://ejournal.stitpn.ac.id/index.php/fondatia 
lingkungan yang ada di sekitar kehidupan anak tersebut. Proses pendidikan pada anak usia 7-12 tahun tersebut ditempuh secara formal di Sekolah Dasar atau MI. ${ }^{1}$

Pada tingkatan ini peserta didik di haruskan untuk melakukan ransanganransangan kepada peserta didik yang sifatnya dapat membantu kecerdasan anak yang dimiliki baik fisik motorik, intelektual, sosial, maupun emosinya sebagai persiapan untuk masuk kependidikan selanjutnya. Agara kematangan dan kesiapan dari pada kecerdasan anak tersebut bisa maksimal dalam menerima proses pembelajaran

Pembelajaran di Sekolah Dasar mempuyai tujuan yaitu memberikan persiapan kepada anak ketika akan memasuki pendidikan selanjutnya dengan mengembangkan nilai-nilai agama (moral), fisik motorik, kognitif, bahasa, sosial emosional, dan Seni. Dalam hal ini bahasa dan membaca merupakan salah satu aspek yang sangat penting dalam kehidupan sosial anak. Bahasa dan membaca tidak hanya berbentuk bahasa lisan, tetapi bisa juga berupa gambar, tulisan, isyarat.

Membaca merupakan salah satu bagian dari perkembangan bahasa yang dapat di artikan menterjemahkan simbol atau gambar kedalam suara kemudian di kombinasikan dengan kata-kata yang disusun agar seseorang dapat memahami bacaan tersebut. Membaca dan berhitung merupakan salah satu hal yang penting bagi seseorang agar dapat mengetahui tentang banyak hal. Maka dalam artikel ini akan membahas tentang bagaimana pembelajaran bahasa indonesia dan membaca dalam pembelajran di tingkat sekolah dasar dan MI, dengan tujuan agar para peserta didik khususnya membaca siswa dapat lancar dengan cepat.

\section{Pembelajaran Bahasa Indonesia di Sekolah Dasar}

Bahasa adalah satu-satunya yang dimiliki oleh indifidu insani yang berfungsi bagi semua kegiatan gerak manusia sepanjang keberadaan manusia itu. Sebagai mahluk yang berbudaya dan bermasyarakat tidak ada kegiatan manusia yang tidak disertai dengan bahasa. Fungsi utama bahasa adalah sebagai alat komunikasi dan alat intraksi dengan manusia lainnya, tanpa bahasa hidup kita akan sepi sunyi tanpa

${ }^{1}$ Nuraidi, Pengajaran Membaca Permulaan Di Sekolah Dasar (Yogyakarta: Pustaka Pelajar, 2008), hlm.18. 
makna. Bagi linguistik ilmu khusus untuk membahas bahasa, bahasa adalah system tanda bunyi yang disepakati.

Bahasa adalah merupakan sistem, maksudnya bahwa bahasa tersebut dibentuk oleh sebuah komponen yang bersifat secara tetap dan dapat dikaedahkan. Selain bersifat sistem bahasa juga bersifat sistemis. Sistem dimana bahasa tersebut tersusun rapi menurut suatu pola tertentu, bukan tersusun baik secara acak ataupun secara sembarangan. Adapun sistemis maksudnya bahasa bukan berdasarkan sistem tunggal melainkan terdiri dari subsistem. ${ }^{2}$

Asal Mula Bahasa Indonesia dari segi bahasa yang digunakan Bahasa Indonesia adalah Bahasa Melayu, sebuah Bahasa Austronesia yang digunakan sebagai lingua franca di Nusantara kemungkinan sejak abad-abad awal penanggalan modern, paling tidak dalam bentuk informalnya. Bentuk bahasa keseharian dinamakan dengan istilah Melayu Pasar. Bentuk tersebut sangat menyentuh sebab begitu mudah dimengerti dan dipahami, kesalahan sangat besar karena terlalu toleransi dan mudah menyerap istilah-istilah lain.

Melayu tinggi merupakan Bentuk yang lebih resmi, sebab bahasa tersebuh boleh di gunakan oleh keluarga kerajaan di sekitar Sumatera, Malaya, dan Jawa. Bentuk bahasa ini lebih sulit karena penggunaanya sangat sulit. Kolonial Belanda beranggapan bahwa kelenturan Melayu Pasar akan menggangu keberadaan bahasa dan budaya. Sehingga Belanda mempromosikan Bahasa Melayu Tinggi, dengan cara menerbitan karya sastra dalam Bahasa Melayu Tinggi oleh Balai Pustaka.

Tetapi Bahasa Melayu Pasar sudah telanjur dipakai oleh banyak pedagang yang melewati Indonesia, kemudian bahasa melayu digunakan sebagai lingua franca (bahasa pergaulan), namun pada saat tersebut belum diminati sebagai bahasa ibu. Biasanya masih digunakan bahasa daerah yang jumlahnya bisa sampai sebanyak 360 .

Awal munculnya Bahasa Indonesia sebagai jati diri bangsa berawal dari kongres Sumpah Pemuda yang di laksanakan pada tanggal 28 Oktober 1928, pada Kongres Nasional kedua di Jakarta, dibuatlah penggunaan Bahasa Indonesia sebagai bahasa untuk Negara Indonesia menyambut kemerdekaan. Soekarno pada saat

${ }^{2}$ Farida dan Rahim, Pengajaran Membaca Di Sekolah Dasar Jakarta : PT Bumi Aksara, 2011), hlm. 17. 
tersebut tidak memilih bahasanya Jawa (yang sebenarnya juga bahasa mayoritas pada saat itu), akan tetapi beliau memilih Bahasa Indonesia yang di dasarkan dari Bahasa Melayu seperti dituturkan pada saat masih di Riau. ${ }^{3}$

Jadi, Bahasa Indonesia itu sudah sangat penting bagi kehidupan manusia bahkan sejak dahulu kala, Bahasa Indonesia di olah sampai menjadi sangat sempurna sehingga bisa di terima dan cepat dimengerti oleh banyak orang.

\section{Tujuan Pembelajaran Bahasa Indonesia}

Berbicara tentang tujuan pembelajaran bahasa indonesia, Prof. Anderson mengemukakan ada enam tujuan dasar yaitu. ${ }^{4}$ Pertama. Bahasa merupakan sebuah system, maksudnya: bahasa bukanlah sejumlah unsur yang terkumpul secara tak beraturan melainkan sebaliknya. Dengan kata lain bahasa merupakan sejumlah unsur yang beratutran, kemudian unsur-unsur bahasa tersebut diatur oleh kaidah pola yang teratur dan berulang, baik dalam tata bunyi, tata bentuk kata maupun tata kalimat.

Kedua, Bahasa sebagai lambang. Artinya: bahasa sebagai lambang kerap digunakan oleh masyarat untuk menginformasikan sesuatu. Dalam keseharian semua itu tidak terlepas dari lambang atau simbol. Sebagai contoh, bendera kuning digunakan sebagai lambang adanya kematian, warna merah melambangkan keberanian dan lambang putih kesucian.

Ketiga, Bahasa itu adalah bunyi. Artinya: bukan semua bunyi bisa dikatakan sebuah bahasa. Namun bunyi yang dihasilkan oleh ucap manusia saja yang bisa dikatan bahasa. tetapi bukan semua bunyi yang dihasilkan dari alat ucap manusia yang dapat disebut bahasa. Misalkan batuk, bersin bukanlah bahasa hanya saja berupa ujaran yang disebut bahasa.

Keempat, Bahasa itu bermakna. Artinya: bahasa itu adalah lambang yang beruwujud bunyi. Apakah yang dilambangkan berwujud bunyi tersebut? Jawabannya

\footnotetext{
${ }^{3}$ Muslich, "Sejarah dan perkembangan bahasa Indonesia" www. Muslich- m.Com, diakses tanggal 7 Agustus 2020.

${ }^{4}$ Anderson, Tujuan Dasar Pembelajaran Bahasa Indonesia (Jakarta: PT Raja Grafindo Persada, 2015), hlm. 76.
} 
adalah yang dilambangkan merupakan suatu pengertian konsep, ide, atau gagasan. Oleh karena itu, lambang harus berdasarkan pada suatu pengertian konsep, ide. Sehinga dapat di simpulkan bahwa bahasa itu harus berdasarkan kepada konsepkonsep yang matang dan ide yang bagus.

Kelima, Bahasa itu konvensional. Artinya: kesepakatan atau perjanjian, bahasa bersifat konvensional artinya, pemakaian lambang bunyi untuk sebuah konsep tertentu harus berdasarkan kesepakatan masyarakat pemakai bahasa. Dan Keenam. Bahasa untuk mengidentifikasikan diri. Artinya: bahasa merupakan ciri pemisah yang sangat urgen di antara ciri budaya yang lain. Oleh sebab itu, dengan bahasa semua kelompok sosial merasa diri sebagai satu kesatuan yang berbeda dengan kelompok lain.

\section{Fungsi Bahasa Indonesia}

Bahasa mempunyi fungsi penting bagi manusia, terutama fungsi komunikatif yaitu alat untuk mengeeuarkan fikiran, gagasan, konsep atau juga perasaan. Oleh karena itu fungsi-fungsi bahasa antara lain dapat dilihat dari sudut penutur, pendengar, topik, kode dan amanat pembicara. Dalam sosiolinguistik di lihat dari sudut penutur, maka bahasa itu berfungsi personal atau pribadi, seorang ahli menyebutnya fungsi emotif. Penutur bukan hanya mengungkapkan emosi lewat bahasa, akan tetapi memperlihatkan emosi ketika menyampaikan tuturannya. Dalam hal tersebut pendengar dapat menduga apakah si penutur sedih, marah atau gembira. ${ }^{5}$

Bahsa jika Dilihat dari segi pendengar atau lawan bicara, maka berfungsi derektif yaitu mengatur tingkah laku pendengar. Bahasa itu tidak hanya membuat pendengar melakukan sesuatu, tetapi melakukan kegiatan yang sesuai dengan yang diinginkan pembicara. Bila dilihat dari segi topik ujaran, maka bahasa ini berfungsi referensial, ada juga yang menyebutnya dengan refresentational, denotatief dan fungsi imformatif. Maka bahasa dalam hal ini berfungsi sebagai alat untuk membicarakan objek atau peristiwa yang ada di sekeliling penutur atau yang ada dalam budaya pada umumnya.

${ }^{5}$ Agustina dan Chaer, Sosiolinguistik (Bandung: Pustaka belajar, 2010), hlm. 11. 
Fungsi referensial inilah yang melahirkan paham tradisional bahwa bahasa itu adalah alat untuk menyatakan fikiran, untuk menyatakan pendapat penutur tentang dunia di sekelilingnya. Bila di telaah dari sisi kode yang digunakan, maka bahasa berfungsi metalingual atau metalinguistik, di mana digunakan untuk membicarakan bahasa itu sendiri. Hal ini dapat dilihat dalam sisi proses pembelajaran bahasa dimana dalam kaidah-kaidah atau aturan-aturan bahasa dijelaskan dengan bahasa. ${ }^{6}$

\section{Pengertian Membaca}

Kemampuan keterampilan membaca merupakan keharusan dalam kehidupan, tidak hanya dari segi kehidupan pendidikan, tetapi juga sangat penting dalam kehidupan bermasyarakat. Dengan membaca peserta didik akan lebih mengetahui segala sesuatu, peserta didik juga akan memiliki pengetahuan dan wawasan yang lebih luas lagi. Keterampilan membaca merupakan modal utama peserta didik. Dengan kemampuan tersebut, peserta didik dapat mempelajari ilmu lain, dapat mengomunikasikan gagasannya dan dapat mengekspresikan dirinya.

Membaca pada hakikatnya suatu hal yang rumit sebab melibatkan banyak hal, bukan hanya melafalkan tulisan, tetapi juga melibatkan aktivitas seperti: visual, berfikir, psikolinguistik, dan metakognitif. Sebagai proses membaca secara visual merupakan proses menerjemahkan symbol tulis (huruf) ke dalam kata-kata lisan. Sebagai suatu proses berfikir, membaca mencakup aktivitas pengenalan kata, pemahaman literal, interpretasi, membaca kritis dan pengalaman kreatif. ${ }^{7}$

Istilah yang sering dipakai dalam memberikan komponen dasar dari proses membaca, yaitu recording, decoding, dan meaning. Recording merujuk pada kata-kata atau kalimat, kemudian mengasosiasikannya dengan bunyi-bunyinya sesuai dengan sistem tulisan yang digunakan, sedangkan proses decoding (penyandian) merujuk pada proses penerjemahan rangkaian grafis dalam kata-kata. Proses recording dan decoding berlangsung pada kelas-kelas rendah, yaitu SD kelas (I, II, dan III) yang lebih dikenal

${ }^{6}$ Farida dan Rahim, Pengajaran Membaca Di Sekolah Dasar Jakarta : PT Bumi Aksara, 2011), hlm. 97.

${ }^{7}$ Muhammad Irfan, Keterampilan Berbahasa Indonesia Untuk PGSD/PGMI (Pancor: Jaya Mandiri Creator, 2013), hlm. 39. 
dengan istilah membaca permulaan. Perkenalan korespondesi pada huruf dengan bunyi-bunyi bahasa. Sementara itu proses memahami makna (meaning) lebih ditekankan di kelas tinggi SD.

Membaca sebagai proses visual merupakan awal penerjemahan syimbol tulis ke bentuk bunyi. Sebagai suatu proses berfikir, maka membaca mencakup hal-hal seperti pengenalan kata, pemahaman literal, interprestasi, membaca kritis dan membaca kreatif. Membaca dari segi proses linguistik, schemata membaca membantunya membangun makna, sedangkan fonologis, semantik, dan fitur sintaksis membantunya mengomunikasikan dan menginterprestasikan pesan-pesan. Proses metakognitif melibatkan seperti perencanaan, pembetulan suatu strategi, pemonitoran dan pengevaluasian. Pembaca pada tahap ini mengidentifikasi tugas pembaca untuk membentuk strategi membaca yang sesuai, memonitor pemahamannya, dan menilai hasilnya. ${ }^{8}$

Perkembangan IPTEK menuntut terciptanya masyarakat yang gemar belajar. Proses belajar yang efektif antara lain dilakukan melalui membaca. Peserta didik yang gemar membaca memperoleh pengetahuan dan alasan baru yang akan meningkatkan kecerdasannya sehingga mereka lebih mampu menjalani tantangan hidup pada masamasa mendatang. Kemampuan membaca merupakan suatu yang sangat penting dalam suatu masyarakat terpelajar. Akan tetapi anak-anak yang tidak memahami pentingnya belajar membaca tidak akan termotivasi untuk belajar. Belajar membaca merupakan usaha yang terus-menerus, dan anak-anak yang melihat tingginya nilai membaca dalam kegiatan pribadinya akan lebih giat belajar dibandingkan dengan anak-anak yang tidak menemukan keuntungan dari kegiatan membaca. ${ }^{9}$

Membaca semakin penting dalam kehidupan baik di lingkungan sekolah maupun di kehidupan masyarakat yang semakin kompleks. Setiap aspek kehidupan melibatkan kegiatan membaca. Di samping itu, kemampuan membaca merupakan tuntutan realitas kehidupan sehari-hari manusia. Beribu judul buku dan berjuta Koran diterbitkan setiap hari. Ledakan informasi ini menimbulkan tekanan bagi guru untuk

${ }^{8}$ Meleong. Membaca (Jakarta: PT Bumi Aksara, 2011), hlm. 65.

${ }^{9}$ Burn (dkk), Pengajaran Membaca Di Sekolah Dasar (Jakarta: PT Bumi Aksara, 2011), hlm. 23. 
menyiapkan bacaan yang memuat informasi yang relevan untuk peserta didiknya. Maupun tidak semua informasi perlu dibaca, tetapi jenis-jenis bacaan tertentu yang sesuai dengan kebutuhan dan kepentingan kita perlu dibaca.

Jika informasi bisa ditemukan dari media lain seperti televise dan radio, namun peran membaca tak dapat digantikan sepenuhnya. Membaca tetap memegang peranan penting dalam kehidupan sehari-hari karena tak semua informasi bisa didapatkan dari media televise dan radio.

\section{Tujuan Membaca}

Membaca hendaknya mempunyai tujuan, karena seseorang yang membaca dengan suatu tujuan, cendrung lebih memahami dibandingkan dengan orang yang tidak mempunyai tujuan. Dalam kegiatan membaca di kelas, guru seharusnya menyusun tujuan membaca dengan menyediakan tujuan khusus yang sesuai atau dengan membantu mereka menyusun tujuan membaca peserta didik itu sendiri. ${ }^{10}$

Tujuan membaca mencakup: a) Kesenangan. b). Menyempurnakan membaca nyaring. c). Memperbaharui pengetahuannya tentang suatu topic. d). Mengaitkan informasi baru dengan informasi yang telah diketahuinya. e). Memperoleh informasi untuk laporan lisan atau tertulis. f). Mengkonfirmasikan atau menolak prediksi. g). Menyampaikan suatu eksperimen atau mengaplikasikan informasi yang diperoleh dari suatu teks dalam beberapa cara lain dan mempelajari tentang struktur teks.

\section{Jenis-jenis Membaca}

Dalam keterampilan membaca ada dua jenis keterampilan membaca yang dapat dilakukan yakni membaca dalam hati dan membaca nyaring. Secara garis besar, membaca dibagi atas dua jenis membaca, yakni membaca nyaring/teknik dan membaca dalam hati. ${ }^{11}$

${ }^{10}$ Masropah, "Jenis-Jenis Kesulitan Belajar Membaca Siswa Kelas II Sekolah Dasar",Skripsi Universitas Bengkulu, Bengkulu, 2014, hlm. 98.

${ }^{11}$ Nuraidi, Pembaca Tehnik Jitu Menjadi Terampil (Yogyakarta: Pustaka Pelajar, 2008), hlm.177. 
Pertama, Membaca Nyaring. Membaca nyaring adalah kegiatan membaca yang dilakukan dengan cara menyuarakan lambang-lambang bunyi. Oleh karena itu membaca nyaring disebut juga membaca bersuara. Dalam membaca nyaring dibutuhkan keterampilan atau teknik-teknik tertentu terutama pada unsur suprasegmental seperti nada, intonasi, tekanan, pelafalan, penghentian dan sebagainya. Karena membaca nyaring mengutamakan teknik-teknik membaca lisan tersebut, maka membaca nyaring sering juga disebut membaca teknik. Sebagai contoh membaca nyaring adalah membaca cerita, membaca puisi, membaca berita dan sebagainya

Kegiatan yang paling penting untuk membangun pengetahuan dan keterampilan berbahasa peserta didik memerlukan membaca nyaring. Membaca dengan tujuan untuk apresiasi dan rekreasi dilaksanakan dalam suasana santai. Membaca dengan teliti dan hati-hati dibangun dengan latihan-latihan yang direncanakan dengan hati-hati terutama membaca materi bacaan yang bersifat informative.

Kedua, Membaca dalam hati. Membaca dalam hati adalah kegiatan membaca yang dilakukan dengan tidak menyuarakan bunyi-bunyi. Karena dilakukan dalam hati, jenis membaca ini memberikan kesempatan kepada peserta didik untuk memahami teks yang dibacanya secara lebih mendalam. Selain itu membaca dalam hati memberikan kesempatan kepada guru untuk mengamati reaksi dan kebiasaan membaca peserta didik.

Membaca dalam hati meliputi membaca ekstensif dan intensif. (a) Membaca Ekstensif/Membaca Cepat. Membaca Ekstensif merupakan teknik membaca secara cepat tanpa mengurangi pemahaman inti bacaan. Membaca ekstensif bertujuan untuk menemukan atau mengetahui secara cepat masalah utama dari teks bacaan. Membaca ekstensif juga disebut sebagai teknik membaca cepat. Membaca cepat adalah membaca yang mengutamakan kecepatannya dengan tidak mengabaikan pemahamannya.

Membaca ekstensif atau membaca cepat meliputi membaca survei, membaca sekilas dan membaca dangkal. Membaca survei dilakukan untuk memeriksa, meneliti daftar kata, judul-judul, bab yang terdapat pada buku-buku yang 
bersangkutan, serta memeriksa bagan, skema, atau aotline buku yang bersangkutan. Contoh membaca survey adalah survey isi buku. Membaca sekilas juga termasuk jenis membaca cepat.

Ada tiga tujuan dalam membaca sekilas yakni sebagai berikut: Untuk memperoleh suatu kesan umum dari suatu bacaan, untuk menemukan hal tertentu dari suatu bacaan dan untuk menemukan atau menempatkan bahan yang diperlukan dalam perpustakaan. Membaca dangkal adalah dilakukan pada saat kita membaca dengan tujuan hiburan, membaca bacaan ringan yang mendatangkan kebahagiaan misalnya cerita lucu, novel ringan dan catatan harian. (b) Membaca Intensif. Membaca Intensif atau membaca pemahaman adalah kegiatan membaca secara mendalam untuk memahami secara lengkap isi buku atau bacaan tertentu. Dengan demikian, dalam membaca intensif diperlukan pemahaman memahami detail atau perincian isi bacaan secara mendalam (intensif).

\section{Hambatan dalam Membaca}

Membaca merupakan proses hambatan yang kompleks. hambatan ini melibatkan sejumlah kegiatan fisik dan mental. Hambatan dalam membaca terdiri dari beberapa aspek salah satunya adalah aspek kurang berpikir. Membaca merupakan proses berpikir. Untuk dapat memahami bacaan, pembaca terlebih dahulu harus memahami kata-kata dan kalimat yang dihadapinya melalui proses asosiasi dan eksperimental. Jika pembaca kurang berpikir maka bacaannya akan terhambat. Kemudian pembaca membuat kesimpulan dengan menghubungkan isi preposisi yang terdapat dalam materi bacaan. Untuk itu pembaca dituntut harus mampu berpikir secara sistematis, logis, dan kreatif. Bertitik tolak dari kesimpulan itu, pembaca dapat menilai bacaan. Kegiatan menilai menuntut kemampuan berpikir kritis. ${ }^{12}$

Peningkatan kemampuan berpikir melalui membaca seharusnya dimulai sejak dini. Guru dapat membimbing peserta didiknya dengan memberikan pertanyaan-pertanyaan yang memungkinkan mereka bisa meningkatkan kemampuan berpikirnya. Pertanyaan-pertanyaan yang diajukan hendaknya merangsang siswa

${ }^{12}$ Syafi ie, Pengajaran Membaca Di Sekolah Dasar (Jakarta: PT Bumi Aksara, 2009), hlm. 44. 
berpikir, seperti pertanyaan mengapa dan bagaimana. Jadi, pertanyaan yang diajukan sehubungan dengan bacaan tidak hanya pertanyaan yang menghasilkan jawaban berupa fakta.

Aspek non afektif merupakan proses membaca yang kurang berkenaan dengan kegiatan memusatkan perhatian, membangkitkan kegemaran membaca (sesuai dengan minatnya), dan menumbukan motivasi membaca ketika sedang membaca. Pemusatan perhatian, kesenangan, motivasi yang tinggi diperlukan dalam membaca. Anak-anak SD/MI seharusnya berlatih memusatkan perhatiannya pada bahan bacaan yang dibacanya. Guru SD/MI bisa melatih peserta didiknya memusatkan perhatian dengan memberikan suatu bacaan yang menjadi minat mereka. Tanpa perhatian yang penuh ketika membaca, peserta didik sulit mendapatkan sesuatu dari bacaan. Motivasi dan kesenangan membaca peserta didik sangat membantu untuk memusatkan perhatian pada bacaan. ${ }^{13}$

\section{KESIMPULAN}

Bahasa adalah satu-satunya yang dimiliki manusia yang tidak pernah lepas dari semua kegiatan gerak manusia sepanjang keberadaan manusia itu. Sebagai mahluk yang berbudaya dan bermasyarakat tidak ada kegiatan manusia yang tidak disertai dengan bahasa. Fungsi utama bahasa adalah sebagai alat komunikasi dan alat intraksi dengan manusia lainnya, tanpa bahasa hidup kita akan sepi sunyi tanpa makna. Bagi linguistik ilmu yang khusus mempelajari bahasa yang dimaksud dengan bahasa adalah system tanda bunyi yang disepakati.

Membaca pada hakikatnya adalah suatu yang rumit yang melibatkan banyak hal, tidak hanya melafalkan tulisan, tetapi juga melibatkan aktivitas visual, berpikir, psikolinguistik, dan metakognitif. Sebagai proses visual membaca merupakan proses menerjemahkan symbol tulis (huruf) ke dalam kata-kata lisan. Sebagai suatu proses

${ }^{13}$ Henry dan Guntur, Pembelajaran Bahasa Indonesia (Bandung: PT Angkasa, 2008), hlm. 235. 
berpikir, membaca mencakup aktivitas pengenalan kata, pemahaman literal, interpretasi, membaca kritis dan pengalaman kreatif. ${ }^{14}$

Tiga istilah sering digunakan untuk memberikan komponen dasar dari proses membaca, yaitu recording, decoding, dan meaning. Recording merujuk pada kata-kata atau kalimat, kemudian mengasosiasikannya dengan bunyi-bunyinya sesuai dengan sistem tulisan yang digunakan, sedangkan proses decoding (penyandian) merujuk pada proses penerjemahan rangkaian grafis dalam kata-kata. Proses recording dan decoding biasanya berlangsung pada kelas-kelas rendah, yaitu SD kelas (I, II, dan III) yang dikenal dengan istilah membaca permulaan. Perkenalan korespondesi pada huruf dengan bunyi-bunyi bahasa. Sementara itu proses memahami makna (meaning) lebih ditekankan ke kelas tinggi SD.

\section{DAFTAR PUSTAKA}

Agustina dan Chaer, Sosiolinguistik. Bandung: Pustaka belajar, 2010.

Anderson, Tujuan Dasar Pembelajaran Bahasa Indonesia. Jakarta: PT Raja Grafindo Persada, 2015.

Burn (dkk), Pengajaran Membaca Di Sekolah Dasar. Jakarta: PT Bumi Aksara, 2011.

Farida dan Rahim, Pengajaran Membaca Di Sekolah Dasar. Jakarta : PT Bumi Aksara, 2011.

Henry dan Guntur, Pembelajaran Bahasa Indonesia. Bandung: PT Angkasa, 2008.

Masropah, "Jenis-Jenis Kesulitan Belajar Membaca Siswa Kelas II Sekolah Dasar", Skripsi Universitas Bengkulu, Bengkulu, 2014.

Meleong. Membaca (Jakarta: PT Bumi Aksara, 2011.

Muhammad Irfan, Keterampilan Berbahasa Indonesia Untuk PGSD/PGMI . Pancor: Jaya Mandiri Creator, 2013.

Muslich, "Sejarah dan perkembangan bahasa Indonesia" www. Muslich- m.Com, diakses tanggal 7 Agustus 2020.

Nuraidi, Pembaca Tehnik Jitu Menjadi Terampil. Yogyakarta: Pustaka Pelajar, 2008.

Nuraidi, Pengajaran Membaca Permulaan Di Sekolah Dasar. Yogyakarta: Pustaka Pelajar, 2008.

Syafi ie, Pengajaran Membaca Di Sekolah Dasar. Jakarta: PT Bumi Aksara, 2009.

${ }^{14}$ Muhammad Irfan, Keterampilan Berbahasa Indonesia Untuk PGSD/PGMI (Pancor: Jaya Mandiri Creator, 2013), hlm. 39. 